\title{
ARTÍCULOS
}

\section{SOCIAL MEDIA AND TELEVISION: A BIBLIOGRAPHIC REVIEW BASED ON THE WEB OF SCIENCE}

\section{Medios sociales y televisión: revisión bibliográfica a partir de la Web of Science}

Francisco Segado, María-del-Mar Grandío and Erika Fernández-Gómez

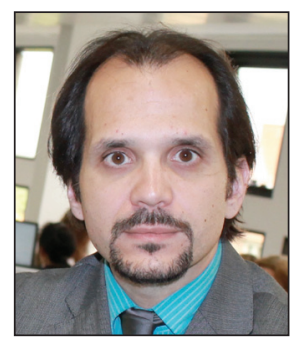

Francisco Segado-Boj holds a B.A. Degree in Journalism and a Ph.D. Degree in Communication from the Complutense University of Madrid (UCM). He is an associate professor at Universidad Internacional de la Rioja (UNIR), where he coordinates the doctoral programme Knowledge society and action in the fields of education, communication, rights and new technologies. Former research fellow at UCM and visiting scholar at University of Central Lancashire. Current director of the Digital Communication \& Society (Coysodi) research group. His work focuses on digital communication (social media and digital journalism), science communication and political cartoons. He has published around twenty papers about these issues in scientific journals such as Telematics \& informatics, First Monday, Historia crítica, Telos, Revista latina de comunicación social, Comunicación y sociedad, or Hispania, among others.

http://orcid.org/0000-0001-7750-3755

Universidad Internacional de la Rioja Gran Vía Rey Juan Carlos I, 41. 26002 Logroño (La Rioja), España francisco.segado@unir.net

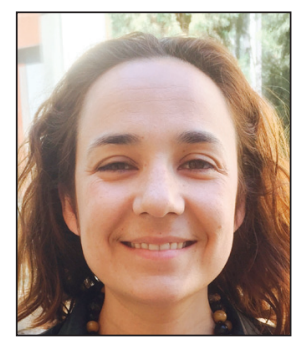

María-del-Mar Grandío is an assistant professor at the School of Communication and Information Studies in the University of Murcia. She lectures on audiovisual fiction and transmedia storytelling. She has been member of the Management Committee of the COST Action "Transforming audiences, transforming societies" (2010-2014) and currently in the COST Action "New possibilities for print and digital media" (2012-2015). Co-author of Sharing economy (EOI, 2014) and Strategies of communion in social media (Gedisa, 2013). She focuses her research on reception studies and new media consume, transmedia audiences and fandom. Index $\mathrm{h}=9$ in Google Scholar. http://orcid.org/0000-0002-2577-4059

Universidad de Murcia, Facultad de Comunicación y Documentación Campus de Espinardo. 30100 Murcia, España mgrandio@um.es

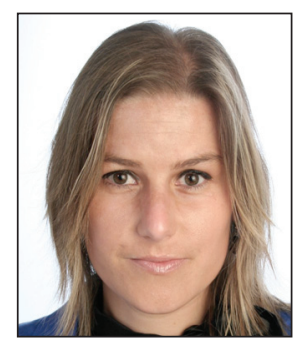

Erika Fernández-Gómez is an assistant professor at Universidad Internacional de La Rioja (UNIR). She got her PhD in the University of Vigo with European mention. She has a degree on Advertising and public relations from the same university and she is specialized in advertising and media management. She is accredited by Aneca. She teaches at UNIR since 2010 in the Degrees in communication and marketing and in the Master degree in audiovisual scripting. She is part of the research group Digital Communication and Society (Coysodi). Her research interests focus on television (especially fiction), advertising, child audience, and social networks. She carried out her doctoral thesis about the Spanish second public channel ( $L a 2)$ and its shows aimed at young targets. http://orcid.org/0000-0002-7088-1814

Universidad Internacional de La Rioja, Facultad de Empresa y Comunicación Gran Vía Rey Juan Carlos I, 41. 26002 Logroño (La Rioja), España erika.fernandez@unir.net 


\begin{abstract}
One of the most important trends in current television research has to do with the increasing impact of social media on viewing and consumption. This article reviews the literature on social media and television included in the Web of Science database from 2005 to 2013 in order to find the main research questions guiding academic research within media studies. The topics investigated included the theoretical approach and definition of social television, the central role of Twitter as the main social tool for second-screen activities, the prominence of "reality TV" as the most social genre on television, and new mainstream forms of television fandom. The conclusion of this article reflects on possible limitations of these studies and new paths of research.
\end{abstract}

\title{
Keywords
}

Social television; Social media; Twitter; Audiences; Review; Web of Science.

\section{Resumen}

Una de las principales tendencias en la investigación actual sobre televisión se centra en el creciente papel de los medios sociales en el consumo televisivo. Este artículo revisa la bibliografía encontrada sobre medios sociales y televisión en la base de datos bibliográfica Web of Science desde 2005 a 2013. El objetivo es resaltar las cuestiones de investigación que están liderando el estudio tales como el debate sobre la definición de televisión social, el papel central de Twitter como principal herramienta social para la realización de actividades de "segunda pantalla", los formatos de tele-realidad como los más comentados en las redes sociales, junto con otras formas de expresión del fenómeno fan. Las conclusiones de este artículo reflexionan sobre posibles limitaciones de estos análysis y subraya nuevas líneas de investigación.

Palabras clave

Televisión social; Medios sociales; Twitter; Audiencias; Revisión; Web of Science.

Segado, Francisco; Grandío, María-del-Mar; Fernández-Gómez, Erika (2015). "Social media and television: a bibliographic review on the Web of Science". El profesional de la información, v. 24, n. 3, mayo-junio, pp. 227-234.

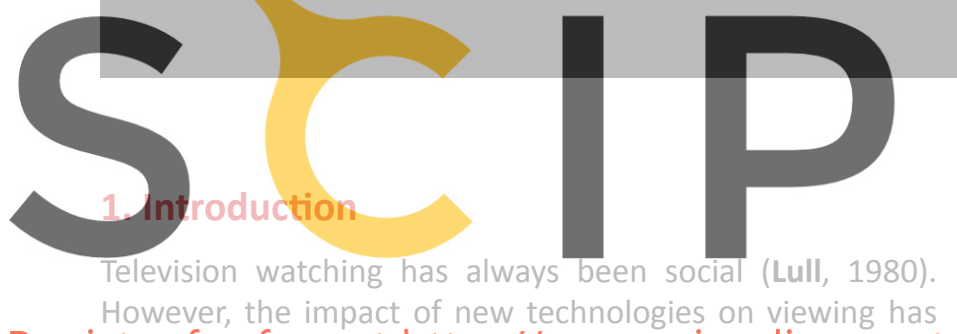

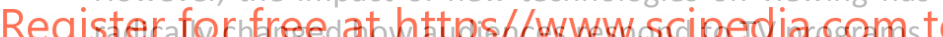

Since the 90's, the permeation of the internet and other new digital communication technologies has provoked deep changes in the so-called legacy media, including transformations in television consumption and production patterns (Owen, 1999; Cesar; Chorianopoulos; Jensen, 2008; Hamaguchi et al., 2012; Noguera et al., 2014). In this new context, where television converges with the internet, new challenges must be addressed not only by the industry but also by researchers. A new kind of advanced television sets which allow non-physical-group TV watching, present information and online communication, as well as support recommendations of TV shows and channels has been developed under the generic label of 'Social television' (Gross; Fetter; Paul-Stueve, 2008). Along with the creation of new television systems, social networks such as Twitter and Facebook play a relevant role in making television a more pleasurable experience. In recent years there has been an increase in the number of papers by scholars studying the role of the audience and the strategies employed by television in this volatile marketplace. This article analyzes the methods, limitations, and conclusions of these studies in the social television field and highlights the main themes represented in the most important database on academic publications: the Web of Science. This review seeks to determine how scholars in Social Scien-

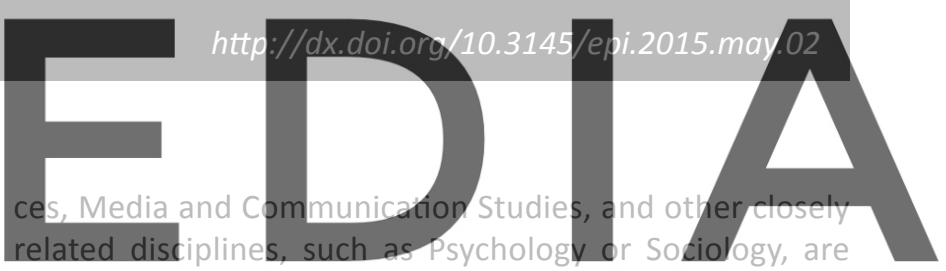

studying the possible relationships and influences of social media on curret the vevisions consumition the watermark

Along with the creation of new television systems, social networks such as Twitter and Facebook play a relevant role in making television a more pleasurable experience

\section{Methodology}

This literature review covers articles from 2005 to 2013 that deal with both television broadcasting and social media (specifically social networking sites). In order to produce the highest quality list, only articles and conference papers indexed in the Web of Science (WoS) core collection were selected. These articles were retrieved by conducting multiple searches for items that included the topic 'social television' as well as the word 'television' and other terms related to social media and web 2.0. These terms were chosen following the same structure outlined in Gold et al. (2011) combining global labels such as 'social media' or 'social network', and other specific features and services such as 'Facebook'. These search terms were employed to locate articles dealing with the wider concept of 'social media' and with 
Table 1. Search terms employed to find articles in WoS core collection

\begin{tabular}{|l|}
\hline Topic $=$ 'Social television' \\
\hline Topic $=$ 'Social media' AND 'Television' \\
\hline Topic $=$ 'Social network ${ }^{* \prime}$ AND 'Television' \\
\hline Topic $=$ 'Online communities' AND 'Television' \\
\hline Topic $=$ 'Blogs' AND 'Television' \\
\hline Topic $=$ 'Facebook' AND 'Television' \\
\hline Topic $=$ 'Twitter' AND 'Television' \\
\hline
\end{tabular}

the most popular services of web 2.0 such as blogs and social networking sites (table 1).

Initially 173 articles were retrieved using the search terms. Their abstracts were manually reviewed and articles were removed that did not specifically deal with the television viewer's use of social media and the relationship between it and television. This left out of the sample several articles that mainly focused on one of these two elements but tangentially mentioned the other (e. g. Lieberman; Koetzle; Sakiyama, 2013; Fogel; Krausz, 2013; Wong; Gupta, 2011, to name a few); articles in which both elements were tangentially mentioned but the focus was a different topic altogether (as Protudjer et al., 2012 or McNeil; Brna; Gordon, 2012); or articles that were restricted to technical issues (such as Montpetit; Médard,2012). After removing these articles, 39 remained and coinprised the cornus of this stu dy. The 39 articles were process analysis to test the following 1. The number of articles sion is growing.

H2. Most of the research about social media and televiRegister fon is publisheq mainly oy Communication Studies jour-

H3. Research on social media and television is mostly empirical, not theoretical.
H4. Most of the research about social media and television uses quantitative methods instead of qualitative or mixed methods.

Besides this quantitative and descriptive analysis, our review was also guided by the following exploratory research question and sub-questions:

RQ1: What are the main areas of interest in the research on social media and television?

RQ1.1 What are the research methods being used in these studies?

RQ1.2 What are the limitations of these studies, so far?

$\mathrm{RQ1.3}$ What are the main conclusions in these studies?

Following other systematic reviews (Schleidgen et al., 2013; Dyer; Das-Nair, 2012) a thematic analysis was used to extract the key issues studied in each article and to identify the aspects mentioned in the sub-questions. This analysis allowed us to identify the most relevant issues regarding social media and television as well as the main approaches and the issues that still remain unknown and unstudied by researchers. Quantitative approaches to the topics were used and global data will be presented. Predominant research topics on social television will be explained more indepth through a qualitative approach based on a thematic analysis on the selected papers.
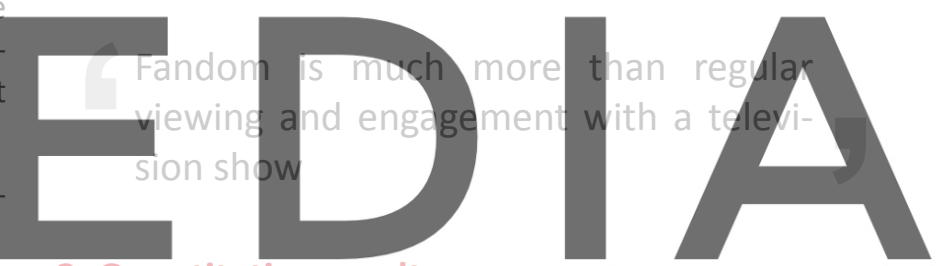

3. Quantitative results

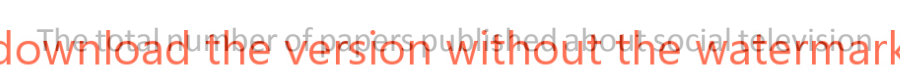
has been growing since 2006 (see figure 1). The concept of Social TV peaked in 2008, although it is still a relevant topic of study. Fandom shows a stable interest among researchers

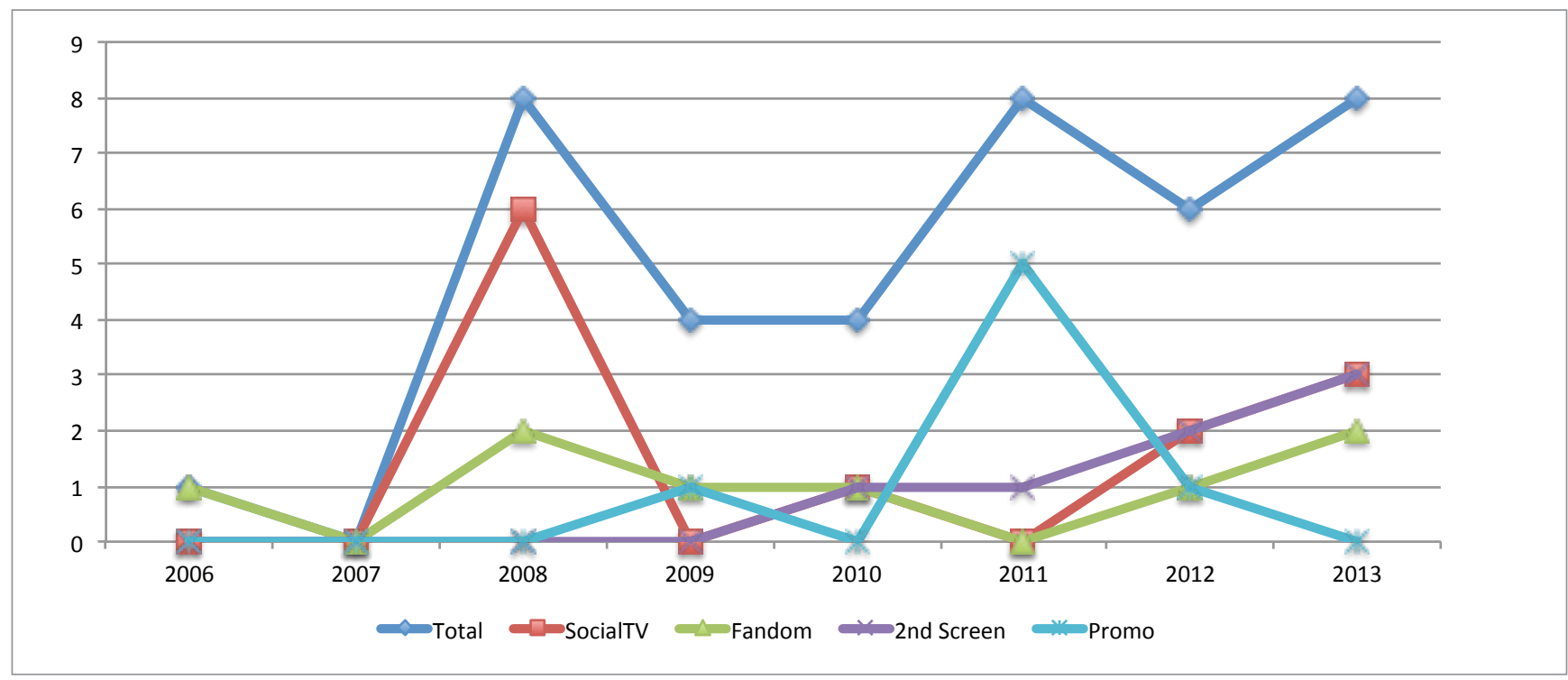

Figure 1. Number of papers published per year and by topic 
Table 2. Number and percentage of papers classified in WoS research areas by topic

\begin{tabular}{|c|c|c|c|c|c|c|c|c|c|c|c|}
\hline \multicolumn{3}{|l|}{ Social TV } & \multicolumn{3}{|c|}{ Fandom } & \multicolumn{3}{|c|}{ Second screen } & \multicolumn{3}{|l|}{ Promo } \\
\hline & n & $\%$ & & n & $\%$ & & $\mathbf{n}$ & $\%$ & & n & $\%$ \\
\hline Computer Science & 8 & 66,7 & Communication & 3 & 37,5 & Communication & 3 & 42,9 & Communication & 5 & 71,4 \\
\hline Engineering & 7 & 58,3 & Asian Studies & 1 & 12,5 & Sociology & 2 & 28,6 & Business \& Economics & 3 & 42,6 \\
\hline Telecommunications & 3 & 25,0 & Cultural Studies & 1 & 12,5 & Computer Science & 1 & 14,3 & Computer Science & 1 & 14,3 \\
\hline Communication & 1 & 8,33 & $\begin{array}{l}\text { Film, Radio \& } \\
\text { Television }\end{array}$ & 1 & 12,5 & Engineering & 1 & 14,3 & $\begin{array}{l}\text { Education \& Educational } \\
\text { Research }\end{array}$ & 1 & 14,3 \\
\hline $\begin{array}{l}\text { Information Science } \\
\text { \& Library Science }\end{array}$ & 1 & 8,33 & Humanities & 1 & 12,5 & Film, Radio \& Television & 1 & 14,3 & Film Radio \& Television & 1 & 14,3 \\
\hline Psychology & 1 & 8,33 & Literature & 1 & 12,5 & Government \& Law & 1 & 14,3 & & & \\
\hline Social Issues & 1 & 8,33 & Multidisciplinary & 1 & 12,5 & Sport Sciences & 1 & 14,3 & & & \\
\hline $\begin{array}{l}\text { Social Sciences-Other } \\
\text { Topics }\end{array}$ & 1 & 8,33 & & & & Telecommunications & 1 & 14,3 & & & \\
\hline
\end{tabular}

since 2006. Fandom is much more than regular viewing and engagement with a television show. It is a framework of taste, an identity and the sense of belonging to a particular community: those who consume and deeply get involved with a specific cultural product. The study of second-screen activities shows a steady increase since 2009

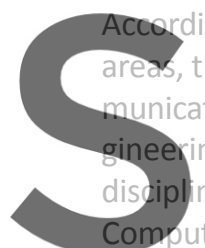
ing to the WoS classificatidn the most interestin social tel ation Studies, followed by Cor ring (see figure 2). Slight differ uter Science and Engineering
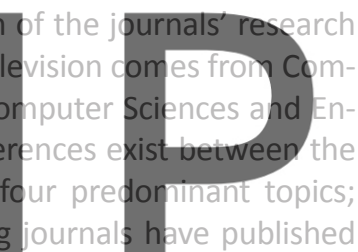

the most about social TV, while Communication journals published the most about second-screen activities (see table 2).

Register for free at https//wWw.scipedia.com to Most of the research on social television has used quantitative methods (surveys, content analysis) more frequently than qualitative tools (discourse analysis, in-depth inter- views, focus groups, etc.). Only seven papers included a theoretical approach to the study. Few papers combine both quantitative and qualitative perspectives or follow a mixed methodology such as network analysis (see figure 3).

Regarding specific topics, articles about the use of social media as a second-screen and a promotional and marke-

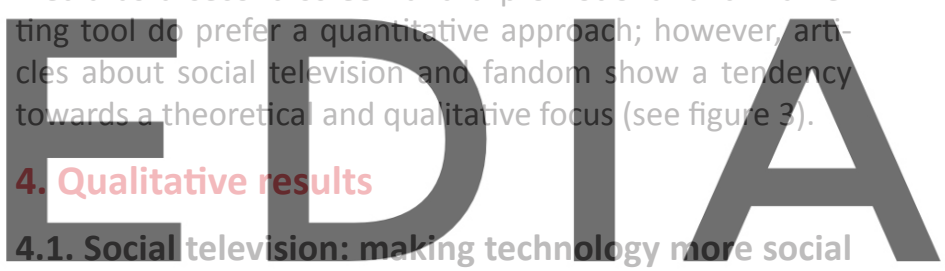

than ever

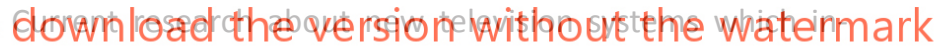
clude social media features has dealt mainly with the way users interact in this new environment (Harboe et al., 2008;

Metcalf et al., 2008) and the perceived usefulness of these devices (Shin, 2013).

For Chorianopoulos and Lekakos (2008, p. 115) social television is an easy-to-use audiovisual system that gets viewers to communicate with each other by employing synchronous or asynchronous interpersonal communication modalities. Pagani and Mirabello define social television as:

"an emerging new technology medium that supports and integrates social interaction, recommendations, ratings, reviews, and interactive participation among viewers via text chat, audio, or even videoconferencing" (2011, p. 43).

According to these studies, social television is seen as an

Figure 2. Percentage of research areas of the Web of Science on social television. 
adequate medium to provide distraction during commercial breaks and other slow parts of a show, but above all is seen as a tool to keep in contact with relatives and other loved ones (Harboe et al., 2008). Not surprisingly, sociability is one of the most valued features of these platforms (Metcalf et al., 2008, Shin, 2013). Shin (2013) concludes that users are mainly attracted to social television because of the social aspects.

Network operators, such as cable television, are investigating multiplatform architecture to deliver a social media television experience to viewers. As explained by Carlucci (2010), social television explores the contributions of television, web-personal computer, and mobile components to the overall experience.

The hybridizing of television and computer offers new pos-

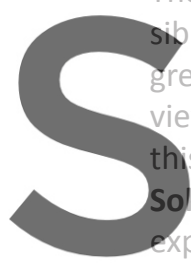

ibilities to enhance the enjoym reater affinity between group viewing experiences. One of the Soler and Sánchez-Svenssdn xperience with the design of a s members
(2008) reptic art
a social tel rs based on shared
gricles published on
eported on an early
elevision system fo senior citizens that used the concept of "presence remote" Register for freessib for eld pry people to notice others and watched television. Another more recent article by Mu et al. (2013) proposed a web-based video storytelling system for members of a large community to edit, broadcast, and report their own stories, similar to what a professional television broadcaster does.

Above all social television is seen as a tool to keep in contact with relatives and other loved ones (Harboe et al., 2008)

\subsection{The role of social media in social television}

Social television researchers have focused much of their attention on social media as a second screen where the television consumption experience is expanded. Social conversation and interaction, implying television consumption, does not only take place in specific television systems, but also through conventional social media and social networking sites. Diakopoulos and Shamma (2010) explained the transformation of media events into "social video experiences" through a case study of conversation on Twitter about the first U.S. presidential television debate in 2008 between
Barack Obama and John McCain. Highfield, Harrington and Bruns (2013) also explored Twitter as a backchannel of a Eurovision contest in Australia. Regarding methodology, the methods more frequently applied for analyzing and tracking
the conversation on social media are discourse and con-
tent analysis (Norman, 2012; Anstead; O'Loughlin, 2011)
and data analysis of socia) n£twork maps (Laysson, 2013),
level of interaction between users (Larsson, 2013; Ans-
tead; O'Loughlin, 2011), Trequency of messages (Anstead)

O'Loughlin, 2011) or type of device used to tweet (Lochrie;

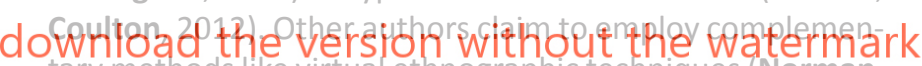
tary methods like virtual ethnographic techniques (Norman, 2012)

A social television system for senior citizens used the concept of 'presence remote' making it possible for elderly people to notice others and be noticed by peers within their local neighborhood as they watched television

These studies have found how the confluence of social media and television has established a new television consumption logic where the "viewer can use social media to publish and learn new information, and engage in discussion" (Anstead; O'Loughlin, 2011: p, 457). Social media has turned into a channel which "may offer a forum for public commentary on and symbolic resistance" to certain issues (Norman, 2012: p. 316). Future studies should investigate to what extent social media comments about television programs reinforce or undermine the dominant discourses in traditional media. 


\subsection{Relationship between social television and rea- lity TV}

The correlation between reality television consumption and the use of social media has been tested through various studies (Stefanone; Lackaff, 2009; Stefanone; Lackaff; Rosen, 2010). According to these studies reality television consumption is positively related to: time spent in social networking site profiles, the number of connections a user has on social networking sites, the proportion of users' connections in online social networks who they have never met face-toface, and the tendency to share their photographs on social networking sites (Stefanone; Lackaff; Rosen, 2010). Yet, this correlation does not imply causation between exposure to reality television and the use of social media. As the authors of these studies remark, these studies do not consider other factors such as personality (voyeuristic trends, for instance) or different preferences toward subgenres of reality television (Stefanone; Lackaff; Rosen, 2010).
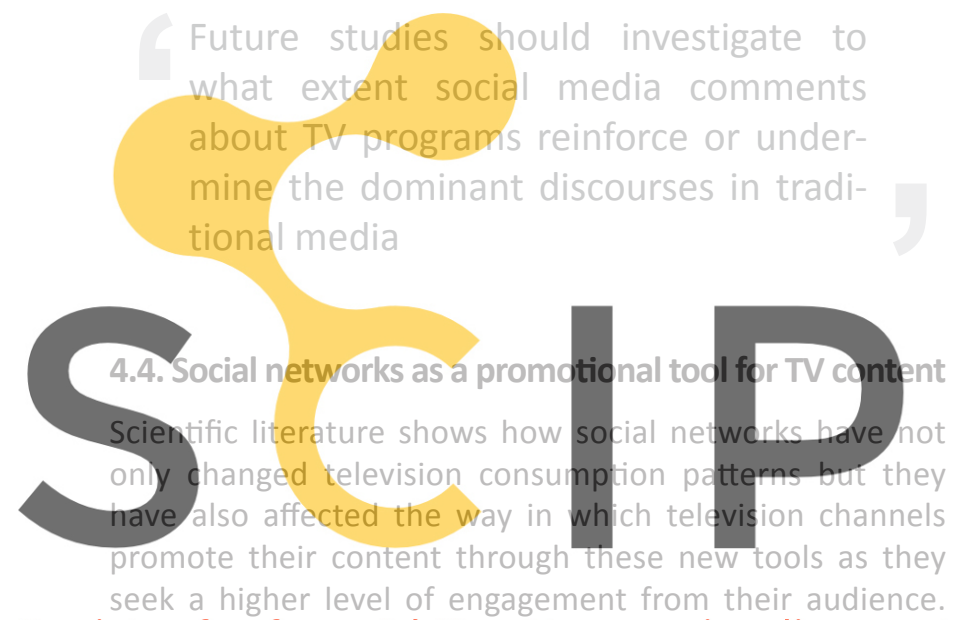

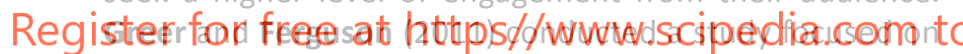
Twitter users to determine what these viewers-followers liked the most about their favorite sites and their motivations for following local television on microblogging networks. Their study concluded that Twitter could be useful to understand the preferences of the audiences. Nevertheless, not all the viewers of a show use social networks actively.

The use of second-screen strategies via the internet increases audience involvement and contributes to the success of television shows. Ytreberg (2009) concluded that the international success of formats such as Pop (American) Idol and Big Brother at the beginning of the millennium could partly be attributed to the rise of a working formula for combining broadcasting with digital platforms. Pagani and Mirabello (2011), through an online sample of 814 European and American users, remarked that participation and interaction in TV web sites such as Veetle TV or Loom TV are boosted by the richness of applications and content offered to users. Campbell (2011) carried out a case study focused on iVilla$g e$, an online community aimed at women that is part of the NBC Group; the article presents how consumers in this community get actively involved in promoting corporate brands through their user-generated content.

\subsection{New expressions on TV fandom as a mainstream activity}

Social television has changed the way fandom feels and expresses itself through new media. Fandom is still a selfawareness and self-determination of fans as fans. But one of the new characteristics is the "mainstreaming of fandom", quite different from the previous understanding of the term based on cult status and unique elite. Leora Hadas and Limor Shifman studied the fan-producer relationship with a case study of the TV series Doctor Who, a cult series revived by a fan turned producer. This case study demonstrates how fans do not present resistance to the mainstream. In their view, fandom must acknowledge that even if web 2.0 platforms make it easy for fans to get organized and express their opinions, their position is no more privileged than it has ever been (2013).

\section{The use of second-screen strategies via the internet increases audience involve- ment and contributes to the success of television shows}

\section{Conclusions}

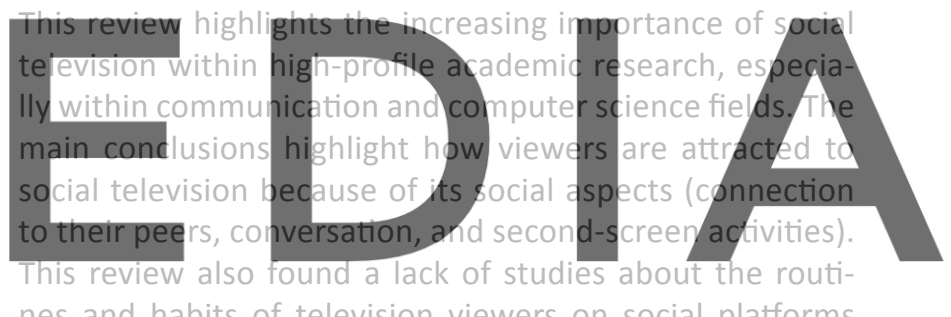

nes and habits of television viewers on social platforms

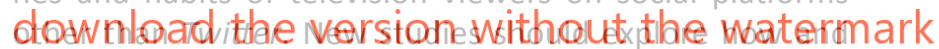

why television viewers comment and interact with others through instant messaging services such as Telegram, Line, or Whatsapp. Regarding methods, very few studies employed user-centered methodologies, such as surveys or focus groups, or in-depth interviews. Social television research should combine quantitative and qualitative methodologies to explain the motivations and reasons which drive users to comment, who users expect to read their comments, and what kind of information they expect to find on social media. Also, studies should expand and cover more cases and scenarios. Most papers analyzed are reduced to comments on a unique case (one show) and one cultural scenario (users from only one country). A cross-cultural approach on social television should be undertaken, along with a wider perspective of the phenomenon taking into account the multiplatform consumption of television within a transmedia scenario.

\section{Note}

This work is partially funded by UNIR Research (http:// research.unir.net), Universidad Internacional de La Rioja (UNIR, http://www.unir.net), under the Research Support Strategy [2013-2015] 


\section{References}

Anstead, Nick; O’Loughlin, Ben (2011). “The emerging viewertariat and $B B C$ question time: television debate and real-time commenting online". The international journal of press/politics, v. 16, n. 4, pp. 440-462.

http://goo.gl/816f40

http://dx.doi.org/10.1177/1940161211415519

Campbell, John-Edward (2011). "It takes an iVillage: Gender, labor, and community in the age of television-internet convergence". Intl journal of communication, v. 5, pp. 492-510. http://ijoc.org/index.php/ijoc/article/view/531/535

Carlucci, John (2010). "Social media television in today's cable systems". In: $7^{\text {th }}$ Consumer communications and networking conf (CCNC), IEEE, pp. 1-5.

http://dx.doi.org/10.1109/CCNC.2010.5421636

Cesar, Pablo; Chorianopoulos, Konstantinos; Jensen, Jens F. (2008). "Social television and user interaction". ACM Comput. entertain., v. 6, n. 1, pp. 1-12

http://doi.acm.org/10.1145/1350843.1350847

Chorianopoulos, Konstantinos; Lekakos, George (2008). "Introduction to social TV: Enhancing the shared experience with interactive TV". International journal of human-computer interaction, v. 24, n. 2, pp. 113-120. http://dx.doi.org/10.1080/10447310701821574

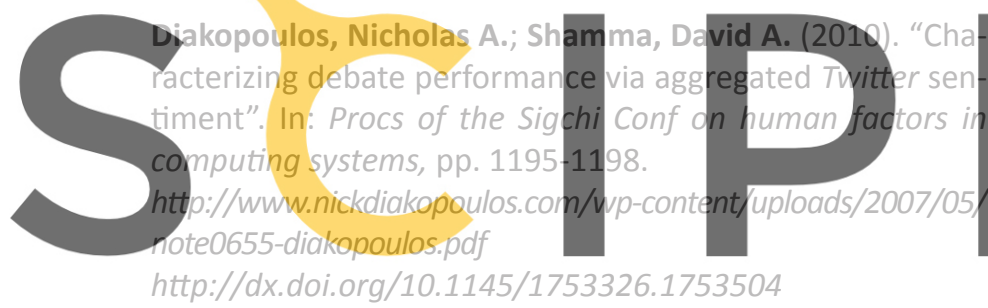

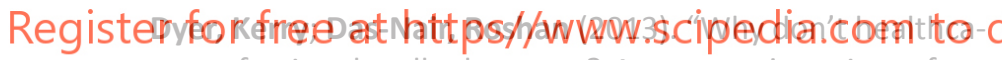
re professionals talk about sex? A systematic review of recent qualitative studies conducted in the United Kingdom". The journal of sexual medicine, v. 10, n. 11, pp. 2658-2670. http://dx.doi.org/10.1111/j.1743-6109.2012.02856.x

Fogel, Joshua; Krausz, Faye (2013). "Watching reality television beauty shows is associated with tanning lamp use and outdoor tanning among college students". Journal of the American Academy of Dermatology, v. 68, n. 5, pp. 784-789. http://dx.doi.org/10.1016/j.jaad.2012.09.055

Gold, Judy; Pedrana, Alisa E.; Sacks-Davis, Rachel; Hellard, Margaret E.; Chang, Shanton; Howard, Steve; Keogh, Louise; Hocking, Jane S.; Stoove, Mark A. (2011). "A systematic examination of the use of online social networking sites for sexual health promotion". BMC public health, v. 11.

http://www. biomedcentral.com/content/pdf/1471-245811-583.pdf

http://dx.doi.org/10.1186/1471-2458-11-583

Greer, Clark F.; Ferguson, Douglas A. (2011). “Using Twitter for promotion and branding: A content analysis of local television Twitter sites". Journal of broadcasting \& electronic media, v. 55, n. 2, pp. 198-214.

http://dx.doi.org/10.1080/08838151.2011.570824
Gross, Tom; Fetter, Mirko; Paul-Stueve, Thilo (2008). "Toward advanced social TV in a cooperative media space". International journal of human-computer interaction, v. 24, n. 2, pp. 155-173.

http://dx.doi.org/10.1080/10447310701821491

Hadas, Leora; Shifman, Limor (2013). "Keeping the elite powerless: Fan-producer relations in the 'nu who' (and new YOU) era". Critical studies in media communication, v. 30, n. 4, pp. 275-291.

http://dx.doi.org/10.1080/15295036.2012.676193

Hamaguchi, Narichika; Miyazaki, Masaru; Nishimura, Satoshi; Fujisawa, Hiroshi (2012). "User behaviour analysis in social TV systems". In: IEEE Int/ conf on consumer electronics (ICCE), pp. 191-192.

http://dx.doi.org/10.1109/ICCE.2012.6161823

Harboe, Gunnar; Massey, Noel; Metcalf, Crysta; Wheatley, David; Romano, Guy (2008). "The uses of social television". Computers in entertainment (CIE), v. 6, n. 1, pp. 1-15. http://dx.doi.org/10.1145/1350843.1350851

Highfield, Tim; Harrington, Stephen; Bruns, Axel (2013). "Twitter as a technology for audiencing and fandom: The \#Eurovision phenomenon". Information, communication \& society, v. 16, n. 3, pp. 315-339.

http://goo.gl/MI3S65

http://dx.doi.org/10.1080/1369118X.2012.756053

Larsson, Anders-Plof (2013). "Tweeting the viewer-use of
Twitter in a talk show context". Journd/ of broadcasting \&
electronic media, v. 57, n. 2, pp. 135-152.
http://dx.doi.org/10.1080/08338151.2013.787081
Lieberman, Joel; Koetzle, Deborah; Sakiyama, Mari (2013).

'Police departments' use of Facebook: Patterns and policy

issues". Police quarterly, v. 16, n. 4 , pp. 438-462.

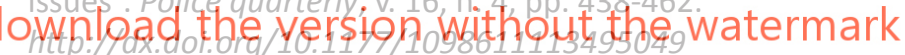

Lochrie, Mark; Coulton, Paul (2012). "Tweeting with the telly on! Mobile phones as second screen for TV". In: Consumer communications and networking conf (CCNC) IEEE, pp. 729-731.

http://core.ac.uk/download/pdf/1558628.pdf http://dx.doi.org/10.1109/CCNC.2012.6181037

Lull, James (1980). "The social uses of television". Human communication research, v. 6, n. 3, pp. 197-209. http://dx.doi.org/10.1111/j.1468-2958.1980.tb00140.x

McNeil, K.; Brna, Paula M.; Gordon, Kevin E. (2012). “Epilepsy in the Twitter era: a need to re-tweet the way we think about seizures". Epilepsy \& behavior, v. 23, n. 2, pp. 127-130. http://dx.doi.org/10.1016/j.yebeh.2011.10.020

Metcalf, Crysta; Harboe, Gunnar; Tullio, Joe; Massey, Noel; Romano, Guy; Huang, Elaine M.; Bentley, Frank (2008). "Examining presence and lightweight messaging in a social television experience". Journal ACM transactions on multimedia computing, communications, and applications, v. 4, n. 4, pp. 27-16.

http://web.mit.edu/bentley/Public/a27-metcalf.pdf http://dx.doi.org/10.1145/1412196.1412200 
Montpetit, Marie-Jose; Médard, Muriel (2012). "Social television: Enabling technologies and architectures". In: Proceedings of the IEEE, v. 100 (Special centennial issue), pp. 1395-1399. http://ieeexplore.ieee.org/stamp/stamp.jsp?tp=\&arnumber=6179504 http://dx.doi.org/10.1109/JPROC.2012.2189804

Mu, Mu; Simpson, Steven; Bojko, Craig; Broadbent, Matthew; Brown, James; Mauthe, Andreas; Race, Nicholas; Hutchison, David (2013). "Storisphere: From TV watching to community story telling" Communications magazine IEEE, v. 51, n. 8, pp.112-119.

http://dx.doi.org/10.1109/MCOM.2013.6576348

Noguera, José-Manuel; Martínez-Sánchez, Jesús; NicolásOjeda, Miguel-Ángel; Pérez-Escolar, Marta; Gómez-Company, Ariana; Grandío, María-del-Mar; Hernández-Gómez, Francisco; Sánchez-Cobarro, Paloma-del-Henar (2014). Economía de la participación. Madrid: Fundación EOI. ISBN: 9788415061458

Norman, Mark (2012). "Saturday night's alright for tweeting: cultural citizenship, collective discussion, and the new media consumption/production of Hockey day in Canada". Sociology of sport journal, v. 29, n. 3, pp. 306-324.

http://www.humankinetics.com/acucustom/sitename/ Documents/Document/tem/03_norman_SSJ2012_0012-ej.pdf

Owen, Bruce M. (1999). The internet challenge to television. Cambridge: Harvard University Press. ISBN: 9780674003897
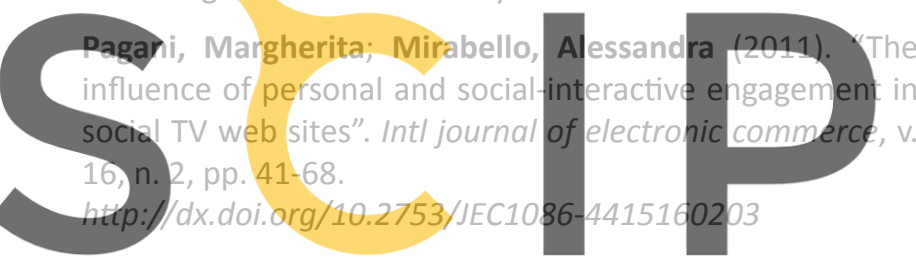

Protudjer, Jennifer-Lisa-Penner; McGavock, Jonathan M. Ramsey, Clare, D.; Sevenhuysen, Gustaaf; Kozyrskyj, Ani-

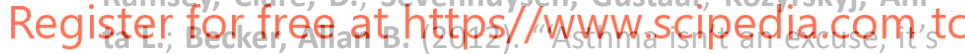
just a condition': Youths' perceptions of physical activity and screen time". Journal of asthma, v. 49, n. 5, pp. 4.96-501. http://dx.doi.org/10.3109/02770903.2012.680637
Schleidgen, Sebastian; Klinger, Corinna; Bertram, Teresa; Rogowski, Wolf H.; Marckmann, Georg (2013). "What is personalized medicine: sharpening a vague term based on a systematic literature review". BMC medical ethics, v. 14, n. 1. http://www.biomedcentral.com/1472-6939/14/55 http://dx.doi.org/10.1186/1472-6939-14-55

Shin, Dong-Hee (2013). "Defining sociability and social presence in social TV". Computers in human behavior, v. 29, n. 3, pp. 939-947.

http://dx.doi.org/10.1016/j.chb.2012.07.006

Sokoler, Tomas; Sánchez-Svensson, Marcus (2008). “PresenceRemote: Embracing ambiguity in the design of social TV for senior citizens". Lecture notes in computer science, $\mathrm{v}$. 5066, pp. 158-162.

http://dx.doi.org/10.1007/978-3-540-69478-6_20

Stefanone, Michael A.; Lackaff, Derek (2009). "Reality television as a model for online behavior: Blogging, photo, and video sharing". Journal of computer-mediated communication, v. 14, n. 4, pp. 964-987.

http://onlinelibrary.wiley.com/doi/10.1111/j.10836101.2009.01477.x/pdf

http://dx.doi.org/10.1111/j.1083-6101.2009.01477.x

Stefanone, Michael A.; Lackaff, Derek; Rosen, Devan (2010). "The relationship between traditional mass media and 'social media': Reality television as a model for social

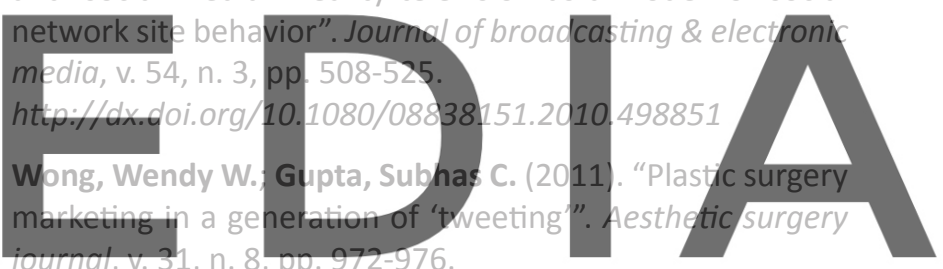

http://dx.doi.org/10.1177/1090820x11423764

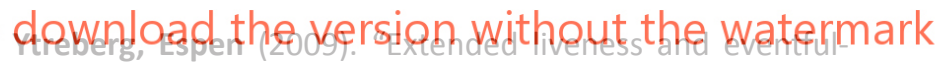
ness in multi-platform reality formats". New media \& society, v. 11, n. 4, pp. 467-485.

http://dx.doi.org/10.1177/1461444809102955

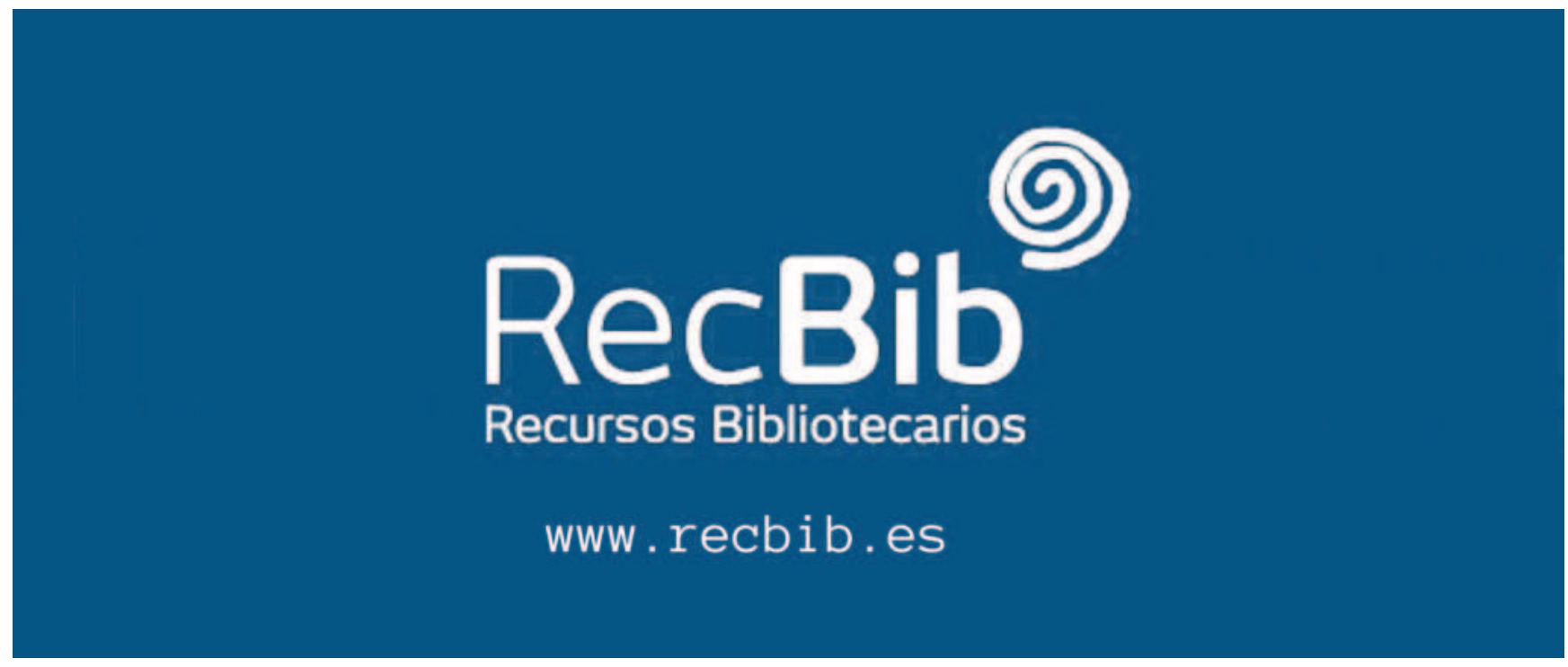

